Research Article

\title{
Simulation and Test of a Fuel Cell Hybrid Golf Cart
}

\author{
Jingming Liang and Qifei Jian \\ School of Mechanical \& Automotive Engineering, South China University of Technology, Guangzhou 510640, China
}

Correspondence should be addressed to Jingming Liang; liangjingming_2013@163.com

Received 17 December 2013; Accepted 2 March 2014; Published 13 May 2014

Academic Editor: Sing Kiong Nguang

Copyright (C) 2014 J. Liang and Q. Jian. This is an open access article distributed under the Creative Commons Attribution License, which permits unrestricted use, distribution, and reproduction in any medium, provided the original work is properly cited.

\begin{abstract}
This paper establishes the simulation model of fuel cell hybrid golf cart (FCHGC), which applies the non-GUI mode of the Advanced Vehicle Simulator (ADVISOR) and the genetic algorithm (GA) to optimize it. Simulation of the objective function is composed of fuel consumption and vehicle dynamic performance; the variables are the fuel cell stack power sizes and the battery numbers. By means of simulation, the optimal parameters of vehicle power unit, fuel cell stack, and battery pack are worked out. On this basis, GUI mode of ADVISOR is used to select the rated power of vehicle motor. In line with simulation parameters, an electrical golf cart is refitted by adding a $2 \mathrm{~kW}$ hydrogen air proton exchange membrane fuel cell (PEMFC) stack system and test the FCHGC. The result shows that the simulation data is effective but it needs improving compared with that of the real cart test.
\end{abstract}

\section{Introduction}

The problem with fossil fuel combustion processes of atmospheric pollution and greenhouse effect has plagued the earth. In order to protect the environment and avoid energy crises, fuel cells are employed as power to drive vehicles. PEMFC due to the high power density, low temperature operating and quick start up, is very suitable for the vehicle power source, whose raw material hydrogen is ubiquitous and its reactant water is environmentally friendly; for this reason, it is an optimal resource [1-3]. However, the production and using costs of fuel cells are extremely expensive, though large fuel cell stacks are used in some buses at home and abroad, most of which are used in testing $[4,5]$. It is of high requirements in both mass and heat transfer of a large stack, resulting in the short using lifespan of the stack. Mini stacks are selected instead of large ones to test the FCHGC so as to reduce costs. They can also be applied in some mini electrical vehicles to reduce the pollution caused by lead-acid battery.

There are some control strategies in fuel cell hybrid vehicle (FCHV), such as fuzzy control and state of charge (SOC) control [6-8], which refer to energy management and SOC balance. This paper employs control strategy based on power following, applying vehicle simulation software ADVISOR and GA to conduct vehicle simulation, comparing its results with the real vehicle testing to analyze the mini
FCHV; it aims to find out the appropriate optimization parameters.

The layout of this paper is as follows. Section 2 demonstrates the use of ADVISOR and GA, as well as the vehicle simulation mode establishment. Section 3 analyses the vehicle structure mode, mainly elaborating the stack size, the batteries mode, and the vehicle out-looking structure that the vehicle matches. Section 4 conducts road test of the vehicle. Section 5 analyses the result of the simulation and the actual testing. Section 6 draws a conclusion of the whole paper.

\section{The Establishment of the Simulation Mode}

2.1. ADVISOR Simulation Model. Vehicle simulation tools are mainly commercial software, such as ADVISOR and CRUISE, as well as simulation tools developed by researchers [9-12]. ADVISOR can match components mode selection of the vehicles beforehand; it can also estimate the energy control strategy by running the vehicles, optimizing all sorts of using parameters $[13,14]$; meanwhile, this software is applied by vehicle manufacture enterprises and vehicle research institutions. ADVISOR employs both the forward and the backward hybrid simulation method, mainly the backward one and the forward simulation as its auxiliaries, in accordance with the energy demands to assign vehicle power energy. 
The internal module of ADVISOR involving parameters is primarily from large business vehicles, while the mini ones need to be developed again, changing some parameters and structure so as to launch the FCHGC simulation. M-file of the main components including FUEL_CELL_defaults_in.m, block_diagram_name.m, VEH_SMART.m, pb.m in the toolkits of ADVISOR, and the driving cycle of the road testing are altered; the block diagram is demonstrated in Figure 1 [15].

2.2. The Objective Functions and Constraint. One of the vehicle objectives is to reduce the fuel consumption; namely, it is to reduce hydrogen consuming as far as the FCHV is concerned. FCHGC energy consumption is to provide power for electric motor, whose power is mainly composed of DC/DC converter (fuel cell stack) and batteries. In order to allocate power of batteries and DC/DC converter rationally, the control strategy necessitates the fuel cell stack work in the high efficient area and maintains the battery's SOC in a reasonable range so as to prevent the batteries from discharging too much power or charging too little and to protect the stack and the batteries, which are introduced in [16].

The calculating function of the fuel cell consuming

$$
\min Q_{\mathrm{H}_{2}}=\int_{0}^{t} f\left(P_{\mathrm{DC} / \mathrm{DC}}, P_{\mathrm{bat}}, P_{\mathrm{acc}}\right) d t
$$

where $Q_{\mathrm{H}_{2}}$ is the consuming of hydrogen in the vehicle operating process, $P_{\mathrm{DC} / \mathrm{DC}}$ is the output power of the converters, $P_{\text {bat }}$ is the output power of battery, and $P_{\text {acc }}$ is accessory power.

Equation (2) is the power calculation of the batteries and the converter $[6,17]$ :

$$
\begin{gathered}
f\left(P_{\mathrm{DC} / \mathrm{DC}}, P_{\mathrm{bat}}\right)=f\left(P_{\mathrm{DC} / \mathrm{DC}}\right)+f\left(P_{\mathrm{bat}}\right)+f\left(P_{\mathrm{acc}}\right), \\
f\left(P_{\mathrm{DC} / \mathrm{DC}}\right)=P_{\mathrm{fc}} * \eta_{\mathrm{DC} / \mathrm{DC}}, \\
f\left(P_{\mathrm{bat}}\right)= \begin{cases}\frac{P_{\text {bat.dis }}}{\eta_{\text {dis }} \overline{\eta_{\mathrm{chg}}}}, \quad P_{\text {bat }} \geq 0, \\
\eta_{\mathrm{dis}} \eta_{\mathrm{chg}} P_{\text {bat.chg }}, \quad P_{\text {bat }}<0,\end{cases} \\
f\left(P_{\mathrm{acc}}\right)=K, \\
\eta_{\text {dis }}=\frac{1}{2}+\frac{1}{2} \sqrt{1-\frac{4 R_{\text {dis }} P_{\text {bat.dis }}}{U_{\text {oc }}}}, \\
\eta_{\text {chg }}=\left(\frac{1}{2}+\frac{1}{2} \sqrt{1-\frac{4 R_{\mathrm{chg}} P_{\text {bat.chg }}}{U_{\text {oc }}}}\right)^{-1},
\end{gathered}
$$

where $P_{\mathrm{fc}}$ represents stack power; $P_{\text {bat.dis }}$ and $P_{\text {bat.chg }}$ are transient discharging and charging power of batteries; $\eta_{\text {chg }}, \overline{\eta_{\text {chg }}}$ are the charging efficiency and average charging efficiency of batteries; $\eta_{\text {dis }}, \overline{\eta_{\text {dis }}}$ are the discharging efficiency and average discharging efficiency of batteries; $\eta_{\mathrm{DC} / \mathrm{DC}}$ is converter efficiency; $K$ is set to be a constant accessories consuming power; $U_{\text {oc }}$ is battery open-circuit voltage; and $R_{\text {chg }}, R_{\text {dis }}$ are batteries charging internal resistance and discharging internal resistance.
Equations (3) are constraining ones:

$$
\begin{gathered}
P_{\mathrm{DC} / \mathrm{DC}}^{\min } \leq P_{\mathrm{DC} / \mathrm{DC}} \leq P_{\mathrm{DC} / \mathrm{DC}}^{\max } \\
P_{\text {bat }}^{\min } \leq P_{\text {bat }} \leq P_{\mathrm{bat}}^{\max } \\
\mathrm{SOC} \_\mathrm{H} \leq \mathrm{SOC} \leq \mathrm{SOC} \_\mathrm{L} \\
P_{\text {req }}=P_{\mathrm{DC} / \mathrm{DC}}+P_{\text {bat }}+P_{\mathrm{acc}} \\
0 \leq V_{\max } \leq 32 \mathrm{~km} / \mathrm{h},
\end{gathered}
$$

where $P_{\mathrm{DC} / \mathrm{DC}}^{\min }$ and $P_{\mathrm{DC} / \mathrm{DC}}^{\max }$ are the minimum and maximum DC/DC power output; $P_{\mathrm{bat}}^{\min }$ and $P_{\mathrm{bat}}^{\max }$ are the minimum and maximum batteries power output; SOC_H and SOC_L are the maximum and minimum SOC; $P_{\text {req }}$ represents the power requirements of the motor; and $V_{\max }$ is the maximum speed of vehicle.

While calculating simulation, DC/DC converter efficiency needs to be added to the ADVISOR mode which has no DC/DC module.

In order to better reflect the features of vehicle dynamic and fuel cell economy, the objective function is revised to be in line with the weighting of the vehicle maximum speed and fuel consuming. The maximum vehicle speed is in accordance with the vehicle designing demands; the estimated maximum vehicle speed is $32 \mathrm{~km}$ per hour.

In accordance with GA to seek the minimum, the maximum vehicle speed is revised to be

$$
V_{\text {modify }}=32-\text { accel.max_speed, }
$$

where accel.max_speed is the maximum speed of vehicle accelerating test.

The objective function of the joint simulation is

$$
\text { Objf }=\lambda_{1} \cdot Q_{\mathrm{H}_{2}}+\lambda_{2} \cdot V_{\text {modify }}
$$

where $\lambda_{1}, \lambda_{2}$ is weighting, and $\lambda_{1}>0, \lambda_{2}>0, \lambda_{1}+\lambda_{2}=1$.

2.3. The Combination of GA and ADVISOR. Based on the concept of chromosome in the biology and genes, GA simulates the mechanism of genes and evolution of the natural biology to optimize, it is especially appropriate for the multiobjective, constrained nonlinear and multimode optimization simulation. Currently, GA is largely applied in the vehicle engineering to conduct optimization simulation, especially the vehicle calculation with features of multiobjective, constrained nonlinear, which are introduced in references $[18,19]$. The basic steps in GA are mentioned in references [19].

The GUI mode of ADVISOR [20], whose mode is visual, easy to operate, and convenient to interact, is usually used, whereas, it is difficult for the GUI mode to carry through combination simulation with other algorithms, whose data cannot be exchanged; in this case, non GUI mode of ADVISOR is employed. A command function [error_code, resp] = adv_no_gui (action, input) is applied in using non-GUI mode.

In accordance with the calculating characteristics of the vehicle model selection and evaluation, $P_{\mathrm{fc}_{-} \text {max }}$ and num ${ }_{\mathrm{bat}}$ 


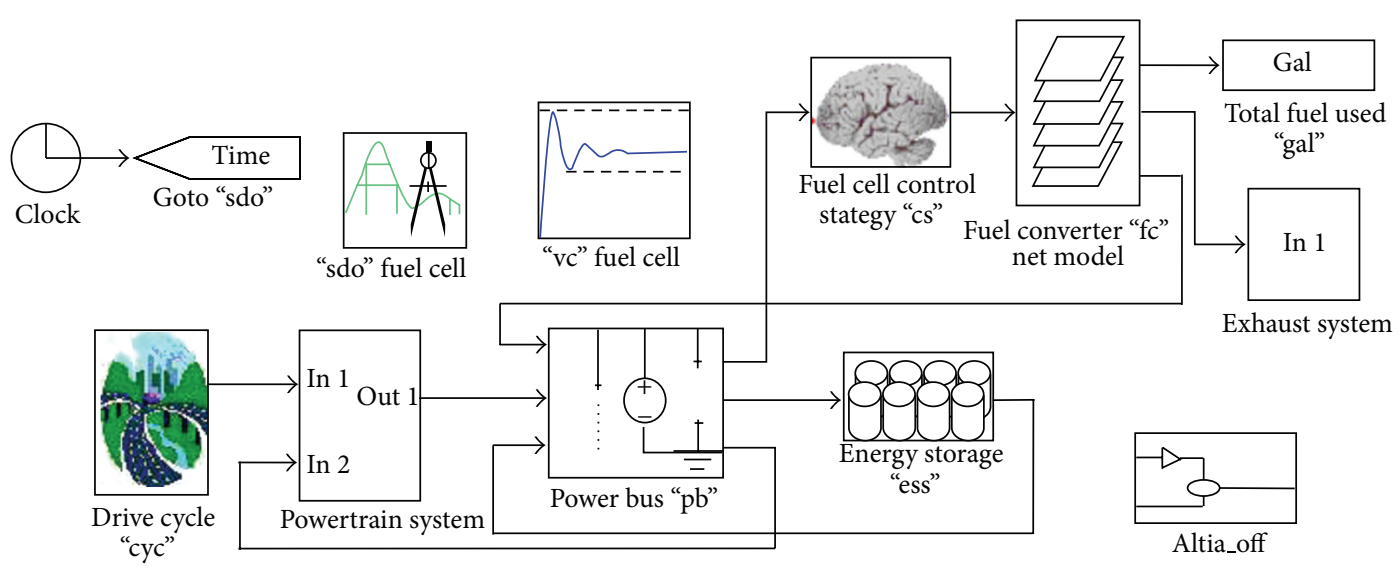

Figure 1: ADVISOR block diagram.

are selected as variables, by revising the commands of nonGUI to simulate, mainly revising the command line [15]:

input.modify.param $=\{$ “fc_max_pwr" $\}$;

input.modify.param $=\{$ “ess_module_num" $\}$;

input.cycle.value $=\{$ “CYC_UDDS_golf” $\}$;

[error, resp] = adv_no_gui (“drive_cycle”, input).

The essential steps of combination simulation are as follows.

(1) Initialize ADVISOR and GA workspace;

(2) Calculate initial population and lead in ADVISOR to work out objective function value. To judge whether terminate the condition or not, quit if feasible, or enter the next step;

(3) The procedure of GA: the objective function value is ranking, operators (select, cross connection or copy, mutation) are selected, obtaining the new population after calculating;

(4) ADVISOR is used to calculate objective function. To judge whether terminate the condition or not, quit if feasible, or enter the next step. The overall procedure is shown in Figure 2.

The GUI functions of ADVISOR are fully used besides the joint simulation. It mainly utilizes the GUI functions to select the motor rated power after making sure the maximum power of the optimal stack and the battery numbers. The ultimate purpose is to make the stack, the batteries, and the motor work coordinately in order to guarantee the dynamic performance and the economy of the vehicle.

\section{The Structural Models of an FCHGC}

The FCHGC is refitted from the golf cart electric vehicle, retaining their fundamental structure, adapting the dynamic components, and adding $2 \mathrm{~kW}$ fuel cell stack and air supplying system; the passengers are cut down from eight to five, the vehicle parameters and system configuration; see Table 1 and Figure 3.
TABLE 1: Parameters of the vehicle structure and power [21].

\begin{tabular}{lc}
\hline Parameters & Data \\
\hline Vehicle structure & $3.75(L) \times 1.35(W)$ \\
Size $(\mathrm{m})$ & $\times 1.88(\mathrm{H})$ \\
Wheelbase $(\mathrm{m})$ & 2.58 \\
Minimum turning radius $(\mathrm{m})$ & 4.5 \\
Maximum speed $(\mathrm{km} / \mathrm{h})$ & 30 \\
Motor voltage $(\mathrm{V})$ & 48 \\
Stack parameters & 110 \\
Number of cells & 66 \\
Rated voltage $(\mathrm{V})$ & $2(0.6 \mathrm{~V} / \mathrm{cell})$ \\
Rated power $(\mathrm{kW})$ & 30 \\
Rated current $(\mathrm{A})$ & \\
Lead-acid battery pack & 8 \\
Number of batteries & 6 \\
Nominal voltage of a single battery $(\mathrm{V})$ & $210(5 \mathrm{hr})$ \\
Electric capacity of a single battery $(\mathrm{A} \mathrm{h})$ & 53 \\
Maximum charging voltage $(\mathrm{V})$ & \\
\hline
\end{tabular}

The FCHGC uses $2 \mathrm{~kW}$ half integration PEMFC stack as main energy provider, mainly providing operating power to the vehicle and charging the batteries once running in the low load road according to demands. For the detailed parameters see Table 1.

The 3-D-210 specialized in electrical vehicle is applied as the power batteries, whose series are composed of eight batteries as auxiliary power system, supplying auxiliary power as soon as the vehicle starts, the stack activated, or when it has insufficient power.

\section{FCHGC Road Test}

Considering the maximum speed of the vehicle does not exceed $32 \mathrm{~km}$ per hour, the maximum climbing gradient does not exceed $11 \%$ and the vehicle cannot do high strength 


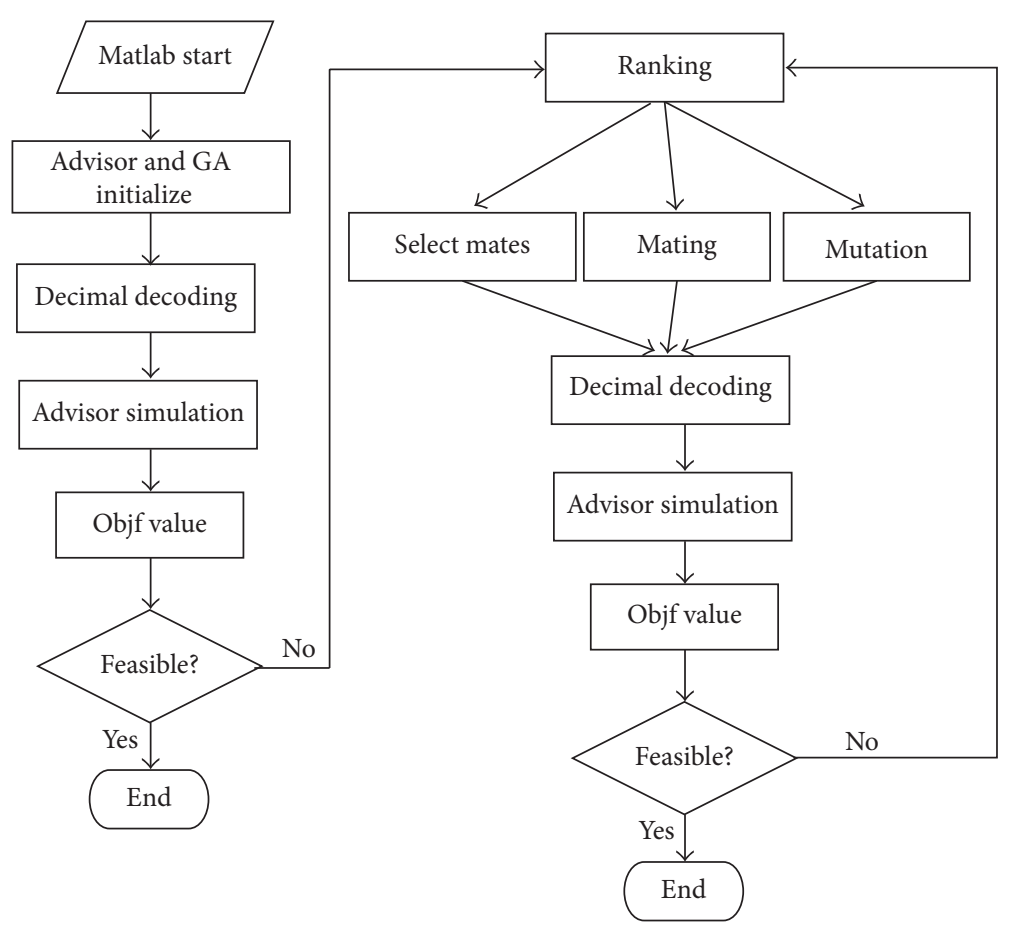

FIGURE 2: Flowchart for combination simulation.

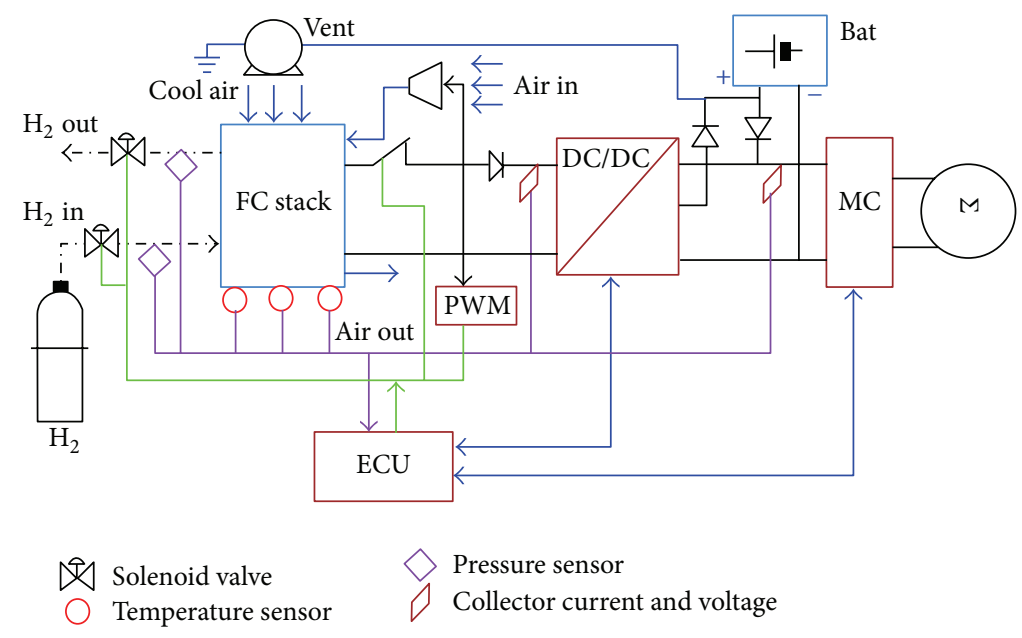

FIGURE 3: Electrical schematic of the vehicle dynamic control.

test, such as CYC_UDDS, CYC_ECE, and CYC_HWFET, also taking into account the FCHGC runs on a flat road. In this case, the vehicle testing group selected a flat road to accelerate and decelerate the cycle test and the relevant climbing test. The test was carried out in the South China University of Technology, North Campus, where the road is concrete pavement and flat. Furthermore, before the real road test, the FCHGC is carried out on the test bench so as to subtract test costs. Some small items are divided during testing, say, discontinuously accelerating, decelerating, and climbing as well as fixing load [22]. The testing is shown in Figure 4.

The test purposes are to obtain information of the stack dynamic performances, such as the maximum power, the corresponding time, and the durability of the stack, as well as the matching condition of the batteries and the stack. It reflects the dynamic performance, the speeding performance, and the maximum speed.

\section{Analysis of Results}

The FCHGC used ADVISOR for simulation, which has no proper driving cycle; therefore, the corresponding revision is made based on CYC_UDDS to form a new driving cycle diagram CYC_UDDS_golf, as shown in Figure 5. The subsequent simulation is carried out based on the new driving cycle. 


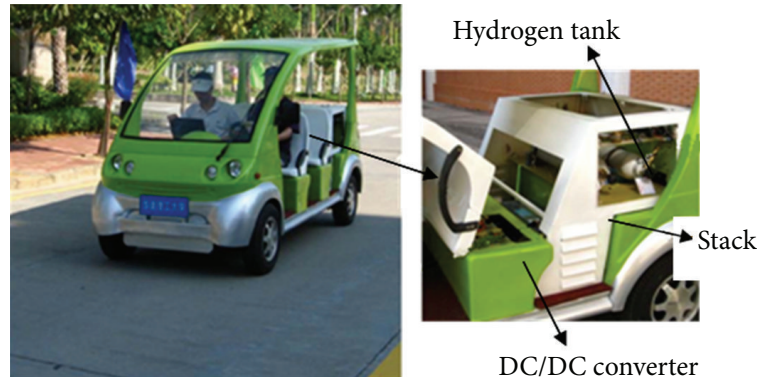

Figure 4: Vehicle test.

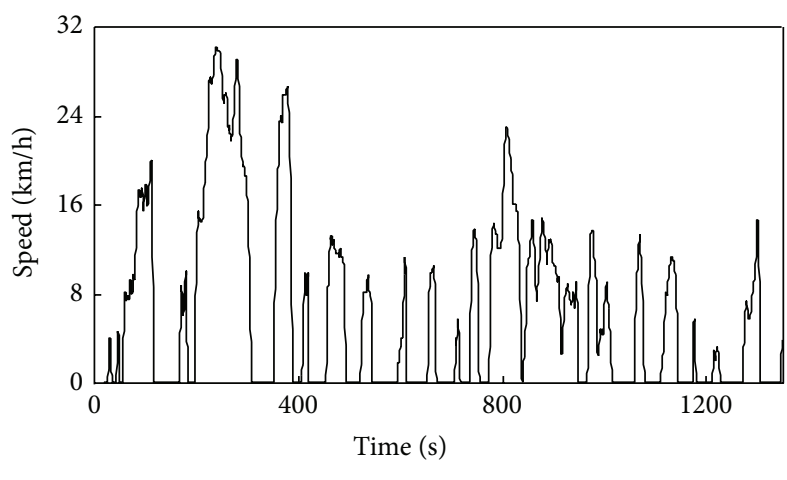

- Speed

FIgURE 5: CYC_UDDS_golf drive cycle.

The weighting $\lambda_{1}=0.7$ and $\lambda_{2}=0.3$ are selected in the simulation to iterate; the result is shown in Figure 6. After 15 generations of iteration, the optimal target and the average target vary to achieve stability, whose fuel consumption is 76.7 $(\mathrm{L} / 100 \mathrm{~km})$. By this time, variable value $P_{\mathrm{fc} \_ \text {max }}$ is $2 \mathrm{~kW}$ and num $_{\text {bat }}$ is 4.7 .

Table 2 is the simulation results; line one demonstrates different parameter symbols, line two to six indicate the simulation results of different weighting, and the last line represents simulation results that simulate through GUI mode after appropriate dynamic component is selected. Table 2 shows the impact on the simulation results caused by different weighting of the objective function. With the increase of fuel economy weight $\lambda_{1}$, the number of batteries increases, whilst the stack power remains $2 \mathrm{~kW}$; meanwhile, fuel consumption is reduced. This testing forms better economy.

Figures 7 to 10 are the comparison between the speed of driving cycle and that of simulation; cyc_mph_r is the speed curve of driving cycle; mpha is the speed curve of simulation. Figures 7 and 8 demonstrate the speed curve of simulation, which cannot reach the speed demands of the driving cycle; the two curves are obviously different, indicating the insufficiency of vehicle power. The two curves in Figure 9 are slightly different, while the two curves in Figure 10 are completely coincident.

In accordance with the simulation, a stack of $2 \mathrm{~kW}$ is selected, while the battery numbers are required to be rounded off, six is selected as num ${ }_{\text {bat }}$. But according to Figure 9, there is a little difference between the two curves;

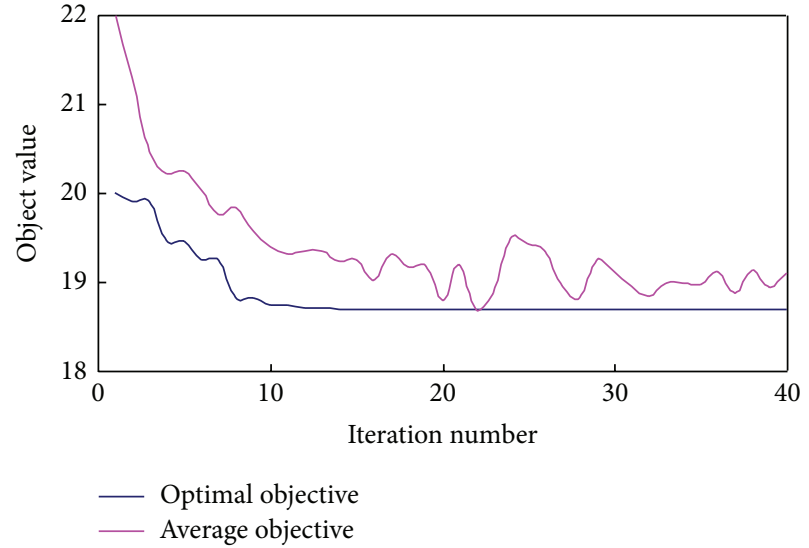

FIGURE 6: Convergence of combination simulation.

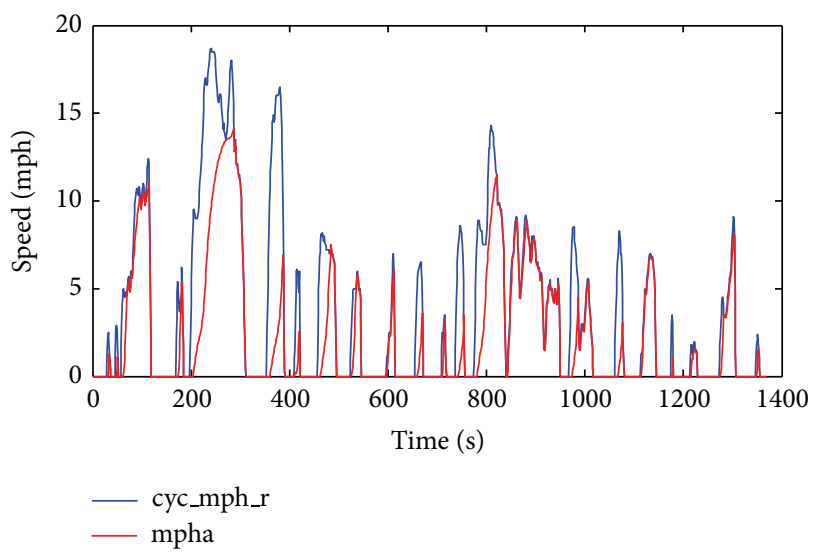

FIgURE $7: \lambda_{1}=0.4, \lambda_{2}=0.6$, the speed of simulation $\&$ drive cycle.

it shows the insufficiency of vehicle power, battery numbers need increasing, for this reason, the battery numbers of the real vehicle are eight. By selecting $2 \mathrm{~kW}$ as $P_{\mathrm{fc} \_ \text {max }}$, eight as num $_{\text {bat }}$, simulating GUI mode of ADVISOR, whose results are shown in Figure 10 and Table 2, the data indicates the minimum fuel consuming of the power matching, satisfying the maximum dynamic demands, achieving the prospective effect.

The above joint simulation estimates the motor rated power to be $3 \mathrm{~kW}$, whether it meets the requirements or not, the following simulation is simulated by means of GUI mode of ADVISOR, whose results are shown from Figure 11 to Figure 13. Figure 11 indicates that in the overall driving cycle, the vehicle driving distance is less than $2.3 \mathrm{~km}$ with a motor under a $2 \mathrm{~kW}$ rated power; moreover, the minimum fuel consumption of the motor power is $34.6 \mathrm{~L} / 100 \mathrm{~km}$ with a motor power of $1.5 \mathrm{~kW}$, and then it increases gradually. Figures 12 and 13 demonstrate that there is a difference between the simulation speed curve and the input driving cycle to the motor rated power less than $2 \mathrm{~kW}$. It indicates that the selection of the undersize of the motor rated power consumes little, but the dynamic performance of vehicle is bad; however, selection with oversize increases the fuel 
TABLE 2: The data of different weighting after the combination simulation.

\begin{tabular}{lccc}
\hline Weighting & num $_{\text {bat }}$ & Fuel Consumption $(\mathrm{L} / 100 \mathrm{~km})^{*}$ & Distance $(\mathrm{km})$ \\
\hline$\lambda_{1}=0.8, \lambda_{2}=0.2$ & 5.2696 & 55.4 & 7.1 \\
$\lambda_{1}=0.7, \lambda_{2}=0.3$ & 4.7304 & 76.7 & 1.6 \\
$\lambda_{1}=0.6, \lambda_{2}=0.4$ & 4.7274 & 76.5 & 1.6 \\
$\lambda_{1}=0.5, \lambda_{2}=0.5$ & 4.7304 & 88.7 & 1.6 \\
$\lambda_{1}=0.4, \lambda_{2}=0.6$ & 4.1657 & 88.7 & 1.4 \\
$\lambda_{1}=0.3, \lambda_{2}=0.7$ & 4.1667 & 46.4 & 1.4 \\
After combination simulation & 8 & 2.3 \\
\hline
\end{tabular}

${ }^{*} \rho_{\mathrm{H}_{2}}=18(\mathrm{~g} / \mathrm{L})$, density of the fuel; $\mathrm{lhv}=120000(\mathrm{~J} / \mathrm{g})$, lower heating value of the fuel.

$\lambda_{1}$ represents the weighting of fuel consumption, $\lambda_{2}$ represents the weighting of dynamic performance.

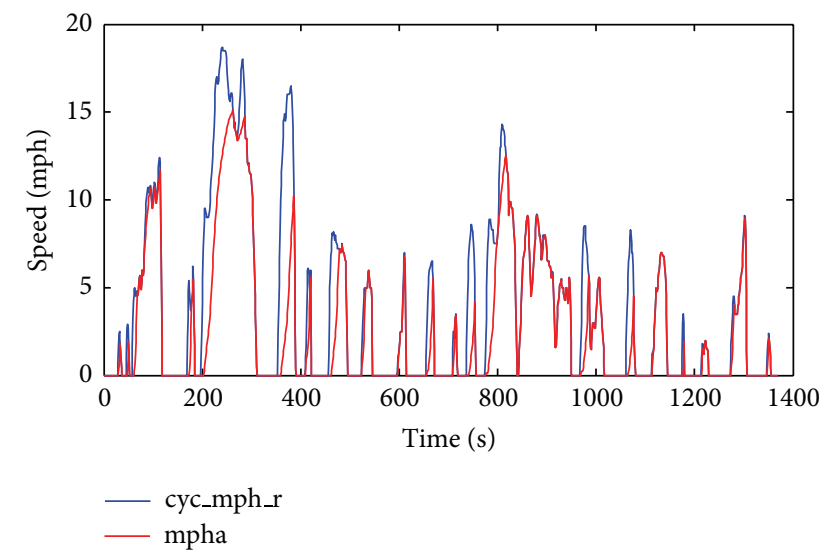

FIgURE 8: $\lambda_{1}=0.6, \lambda_{2}=0.4$, the speed of simulation $\&$ drive cycle.

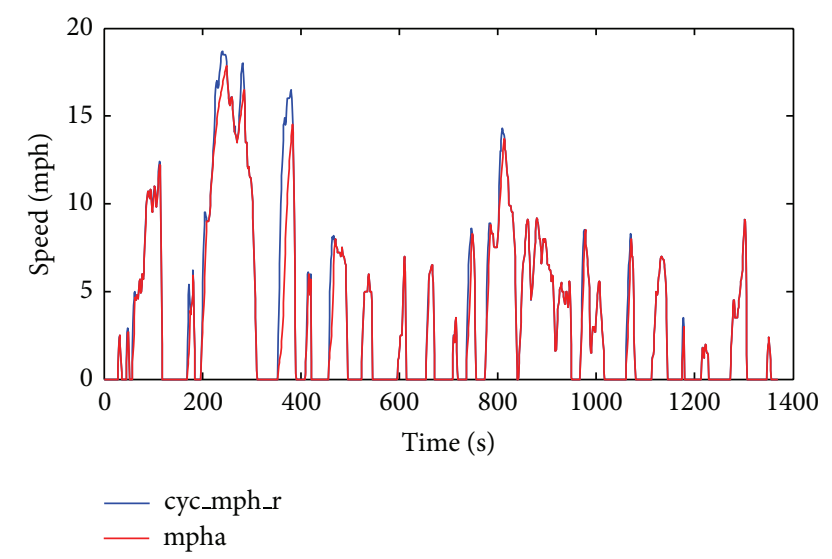

FigURE 9: $\lambda_{1}=0.8, \lambda_{2}=0.2$, the speed of simulation $\&$ drive cycle.

consumption, and in this case, a $3 \mathrm{~kW}$ is optimal to be selected as the rate power of the motor.

Road tests of climbing and flat ground are to verify the using status of the stack power and the batteries, comparing with the simulation results. Figure 11 indicates the hybrid test of the FCHGC, which discontinuously accelerates and decelerates on the road. When motor needs large power, the stack power of real testing is working fluctuation in $2 \mathrm{~kW}$ attachments, however, the maximum stack power of the simulation does not exceed $2 \mathrm{~kW}$. The simulation software

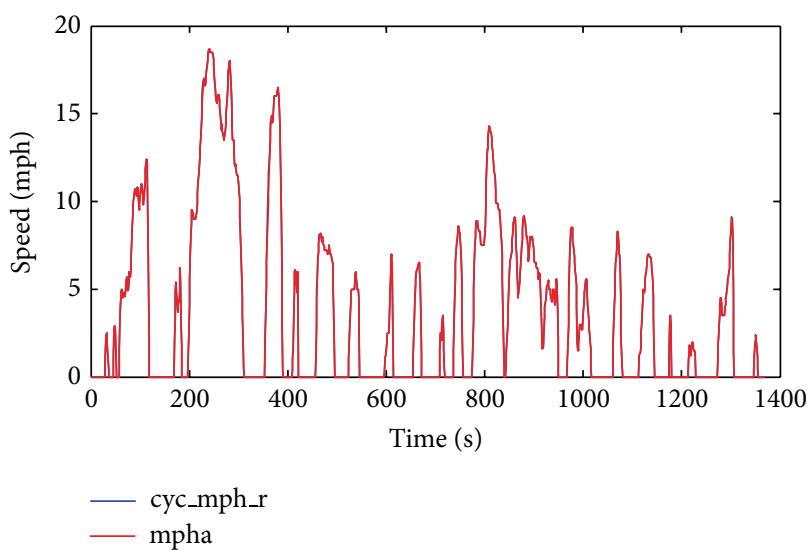

FIGURE 10: The speed of simulation and drive cycle.

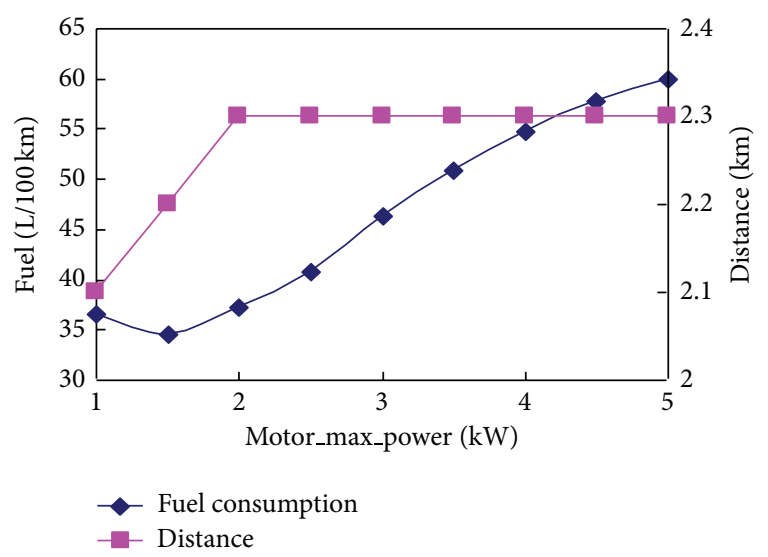

FIGURE 11: Fuel consumption and vehicle versus motor power.

also makes the stack supply the accessories with $300 \mathrm{~W}$ power, while the real vehicle is supplied with batteries.

With a gradient of $11 \%$, the vehicle climbing status is described in Figure 12, which shows the stack power ascends and fluctuates in the road test, not reaching the maximum power $2 \mathrm{~kW}$, while the stack power of the simulation immediately reaches $2 \mathrm{~kW}$ and remains in this stage until the climbing ends. The cause is the vehicle motor power demand increases; the stack is required to provide more power, but it cannot respond immediately, because its reactant reaction 


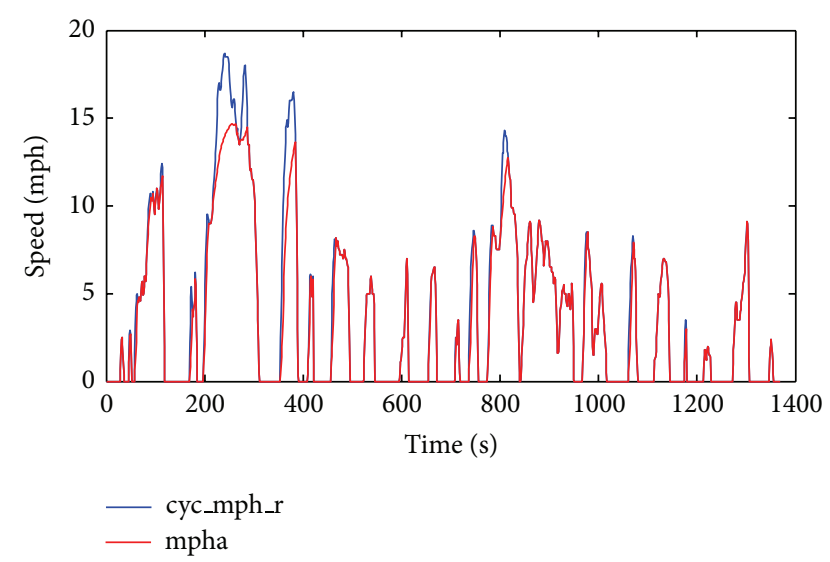

FIgURE 12: $P_{\text {motor }}=1 \mathrm{~kW}$, the speed of simulation and drive cycle.

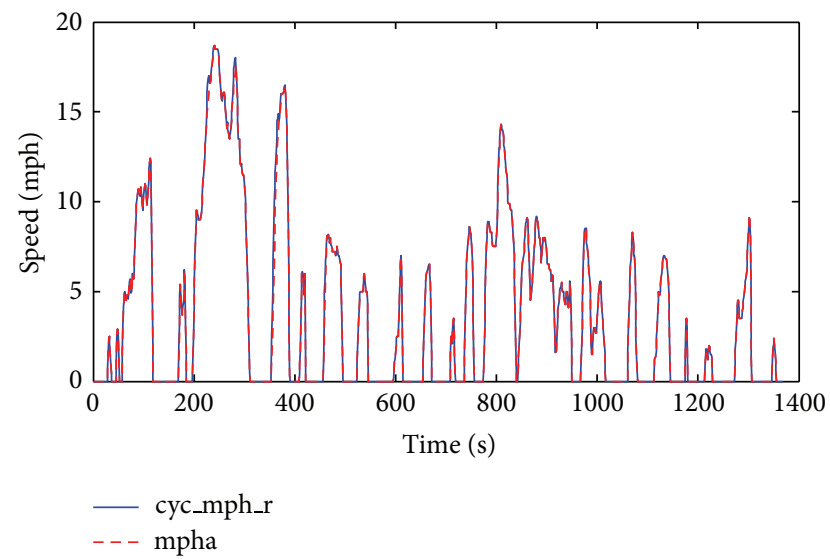

FIGURE 13: $P_{\text {motor }}=2 \mathrm{~kW}$, the speed of simulation and drive cycle.

and by-products and heat transfer need time; these factors cause the stack power oscillation. Simultaneously, in order to protect the stack, DC/DC do not allow too much change of the stack power; therefore, the batteries need to provide more power [23-25]. However, ADVISOR involving mass and heat transfer is static data; therefore, the stack provides the maximum power.

It reflects the discrepancy between the simulation and the real test; simulation accuracy needs improving in practice so as to better serve the vehicle development.

\section{Conclusion}

By analyzing the structure features and the using condition of the FCHGC and the problems emerged in the process of ADVISOR simulation, some viewpoints are concluded as follows.

(1) The joint simulation of GA and ADVISOR can fast and accurately solve the problems of the vehicle power selection, mitigating the product research and development, saving the development cost.
(2) By analyzing the optimization of the FCHGC, the appropriate fuel consumption and dynamic performance of mini PEMFC are found out, which can be widely applied and be used as a research reference for fuel cell vehicles with high-efficiency.

(3) Simulation is one of the necessary work of the vehicle development, while simulation cannot replace real testing because the simulation software has some static data that influences the simulation result; in consequence, there still exists a large improvement.

\section{Nomenclature}

$\begin{array}{ll}P: & \text { Power } \\ R: & \text { Resistance } \\ U: & \text { Voltage } \\ \text { K: } & \text { Constant accessories consuming } \\ \text { SOC_H: } & \text { Maximum SOC } \\ \text { SOC_L: } & \text { Minimum SOC } \\ V: & \text { Speed } \\ \text { num: } & \text { Battery number } \\ \text { GA: } & \text { Genetic algorithm } \\ \text { FCHGC: } & \text { Fuel cell hybrid golf cart } \\ \text { ADVISOR: } & \text { Advanced Vehicle Simulator } \\ \text { FCHV: } & \text { Fuel cell hybrid vehicle } \\ \text { SOC: } & \text { State of charge } \\ \text { PEMFC: } & \text { Proton exchange membrane fuel cell } \\ \text { Q: } & \text { The consuming of hydrogen. }\end{array}$

Subscripts

$\begin{array}{ll}\lambda: & \text { Weighting } \\ \eta: & \text { Efficiency } \\ \text { bat: } & \text { Battery } \\ \text { acc: } & \text { Accessory } \\ \text { DC/DC: } & \text { Direct current converter } \\ \text { fc: } & \text { Fuel cell } \\ \text { dis: } & \text { Discharging } \\ \text { chg: } & \text { Charging } \\ \text { oc: } & \text { Open-circuit } \\ \text { min: } & \text { Minimum } \\ \text { max: } & \text { Maximum } \\ \text { req: } & \text { Requirement. }\end{array}$

\section{Conflict of Interests}

The authors declare that there is no conflict of interests regarding the publication of this paper.

\section{Acknowledgment}

The research was supported by Guangdong Science and Technology Department, China (Funding: no. 2011A090200075, no. 2012B091100330). 


\section{References}

[1] R. Tirnovan and S. Giurgea, "Efficiency improvement of a PEMFC power source by optimization of the air management," International Journal of Hydrogen Energy, vol. 37, no. 9, pp. 7745-7756, 2012.

[2] P. Corbo, F. Migliardini, and O. Veneri, "Performance investigation of $2.4 \mathrm{~kW}$ PEM fuel cell stack in vehicles," International Journal of Hydrogen Energy, vol. 32, no. 17, pp. 4340-4349, 2007.

[3] L. Akyalçin and S. Kaytakoğlu, "Optimization of structural combinations on the performance of a PEMFC's MEA," Journal of Power Sources, vol. 180, no. 2, pp. 767-772, 2008.

[4] R. K. Ahluwalia, X. Wang, J. Kwon et al., "Performance and cost of automotive fuel cell systems with ultra-low platinum loadings," Journal of Power Sources, vol. 196, no. 10, pp. 46194630, 2011.

[5] P. Baptista, M. Tomás, and C. Silva, "Plug-in hybrid fuel cell vehicles market penetration scenarios," International Journal of Hydrogen Energy, vol. 35, no. 18, pp. 10024-10030, 2010.

[6] L. Barelli, G. Bidini, and A. Ottaviano, "Optimization of a PEMFC/battery pack power system for a bus application," Applied Energy, vol. 97, pp. 777-784, 2012.

[7] M. C. Kisacikoglu, M. Uzunoglu, and M. S. Alam, "Load sharing using fuzzy logic control in a fuel cell/ultracapacitor hybrid vehicle," International Journal of Hydrogen Energy, vol. 34, no. 3, pp. 1497-1507, 2009.

[8] S. Caux, W. Hankache, M. Fadel, and D. Hissel, "On-line fuzzy energy management for hybrid fuel cell systems," International Journal of Hydrogen Energy, vol. 35, no. 5, pp. 2134-2143, 2010.

[9] D. Brown, M. Alexander, D. Brunner, S. G. Advani, and A. K. Prasad, "Drive-train simulator for a fuel cell hybrid vehicle," Journal of Power Sources, vol. 183, no. 1, pp. 275-281, 2008.

[10] F. Musio, F. Tacchi, L. Omati et al., "PEMFC system simulation in MATLAB-Simulink environment," International Journal of Hydrogen Energy, vol. 36, no. 13, pp. 8045-8052, 2011.

[11] E. Hosseinzadeh, M. Rokni, S. G. Advani, and A. K. Prasad, "Performance simulation and analysis of a fuel cell/battery hybrid forklift truck," International Journal of Hydrogen Energy, vol. 38, no. 11, pp. 4241-4249, 2013.

[12] Z. Wu, J. Zhang, L. Jiang, H. Wu, and C. Yin, “The energy efficiency evaluation of hybrid energy storage system based on ultra-capacitor and $\mathrm{LiFePO}_{4}$ battery," WSEAS Transactions on Systems, vol. 11, no. 3, pp. 95-105, 2012.

[13] J.-W. Xu and L. Zheng, "Simulation and analysis of series hybrid electric vehicle (SHEV) based on ADVISOR," in Proceedings of the International Conference on Measuring Technology and Mechatronics Automation (ICMTMA '10), pp. 354-357, March 2010.

[14] A. Same, A. Stipe, D. Grossman, and J. W. Park, "A study on optimization of hybrid drive train using advanced vehicle simulator (ADVISOR)," Journal of Power Sources, vol. 195, no. 19, pp. 6954-6963, 2010.

[15] A. Brooker, K. Haraldsson, T. Hendricks, V. Johnson, K. Kelly, and B. Kramer, "ADVISOR Documentation (Version 2002)," National Renewable Energy Lab., April 2002.

[16] A. Ravey, B. Blunier, and A. Miraoui, "Control strategies for fuel-cell-based hybrid electric vehicles: from offline to online and experimental results," IEEE Transactions on Vehicular Technology, vol. 61, no. 6, pp. 2452-2457, 2012.

[17] L. Xu, X. Li, J. Hua, J. Li, and M. Ouyang, "Parameter identification and control strategy optimization of hybrid fuel cell powertrain," Journal of Mechanical Engineering, vol. 45, no. 2, pp. 56-61, 2009.

[18] L. Fang, S. Qin, G. Xu, T. Li, and K. Zhu, "Simultaneous optimization for hybrid electric vehicle parameters based on multi-objective genetic algorithms," Energies, vol. 4, no. 3, pp. 532-544, 2011.

[19] A. Arsalis, M. P. Nielsen, and S. K. Kær, "Modeling and optimization of a $1 \mathrm{kWe}$ HT-PEMFC-based micro-CHP residential system," International Journal of Hydrogen Energy, vol. 37, no. 3, pp. 2470-2481, 2012.

[20] Q. Li, W. Chen, Y. Li, S. Liu, and J. Huang, "Energy management strategy for fuel cell/battery/ultracapacitor hybrid vehicle based on fuzzy logic," Electrical Power and Energy Systems, vol. 43, pp. 514-525, 2012.

[21] Y. Tang, W. Yuan, M. Pan, and Z. Wan, "Experimental investigation on the dynamic performance of a hybrid PEM fuel cell/battery system for lightweight electric vehicle application," Applied Energy, vol. 88, no. 1, pp. 68-76, 2011.

[22] J. Liang and Q. Jian, "Decay analysis of a 5kW PEMFC stack in sightseeing bus," in Proceedings of the 3rd International Conference on Frontiers of Manufacturing Science and Measuring Technology, pp. 1826-1829, 2013.

[23] T. Matsuura, J. B. Siegel, J. Chen, and A. G. Stefanopoulou, "Multiple degradation phenomena in polymer electrolyte fuel cell operation with dead-ended anode," in Proceedings of the 9th Fuel Cell Science, Engineering and Technology Conference, pp. 19, Washington, DC, USA, August 2013.

[24] J. J. Hwang, W. R. Chang, F. B. Weng, A. Su, and C. K. Chen, "Development of a small vehicular PEM fuel cell system," International Journal of Hydrogen Energy, vol. 33, no. 14, pp. 3801-3807, 2008.

[25] P. Corbo, F. Migliardini, and O. Veneri, "Experimental analysis of a $20 \mathrm{kWe}$ PEM fuel cell system in dynamic conditions representative of automotive applications," Energy Conversion and Management, vol. 49, no. 10, pp. 2688-2697, 2008. 

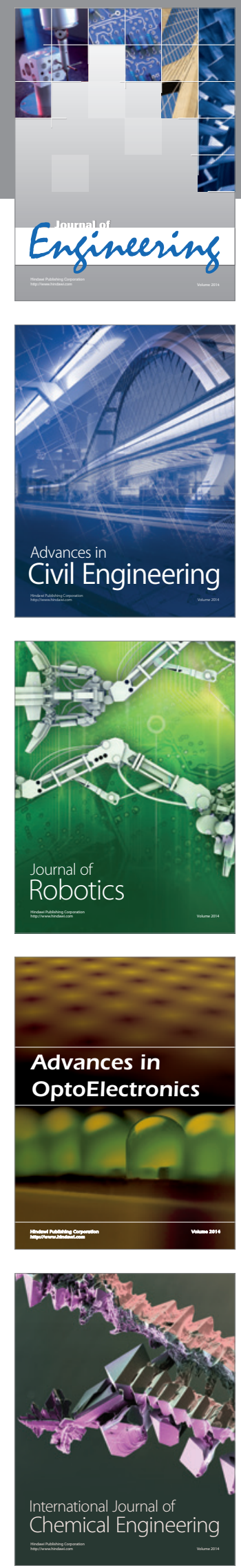

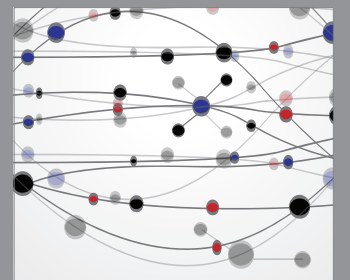

The Scientific World Journal
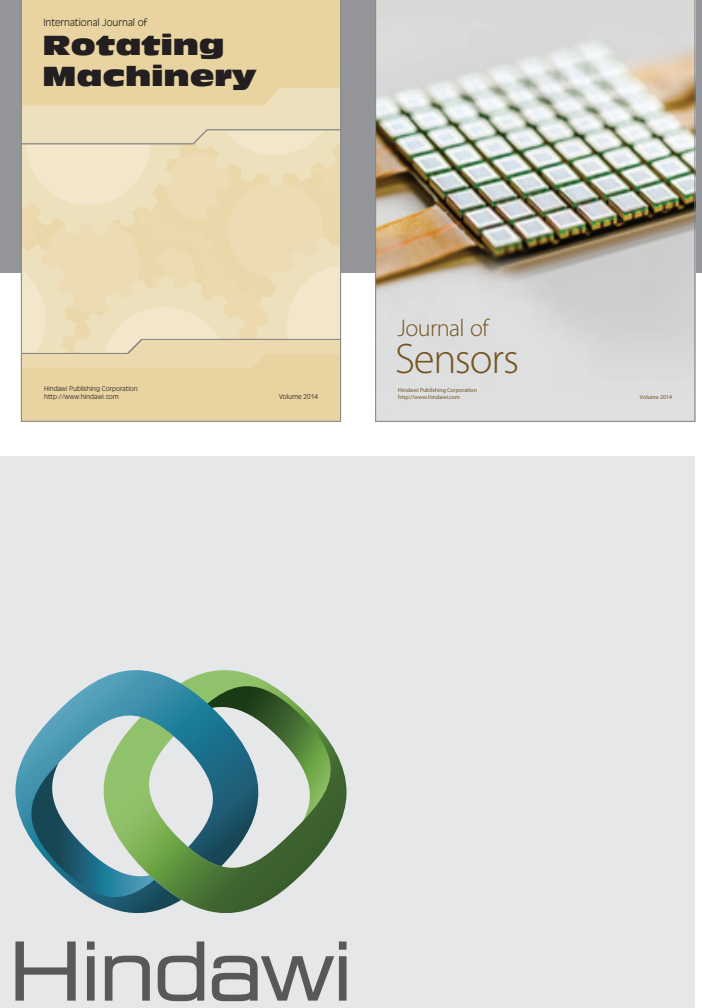

Submit your manuscripts at http://www.hindawi.com
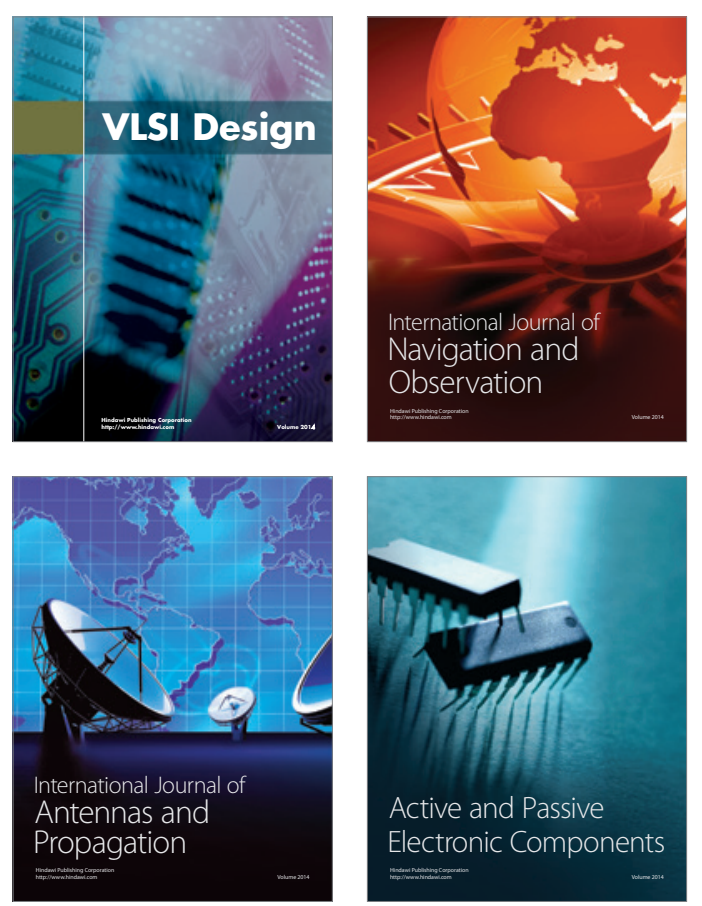
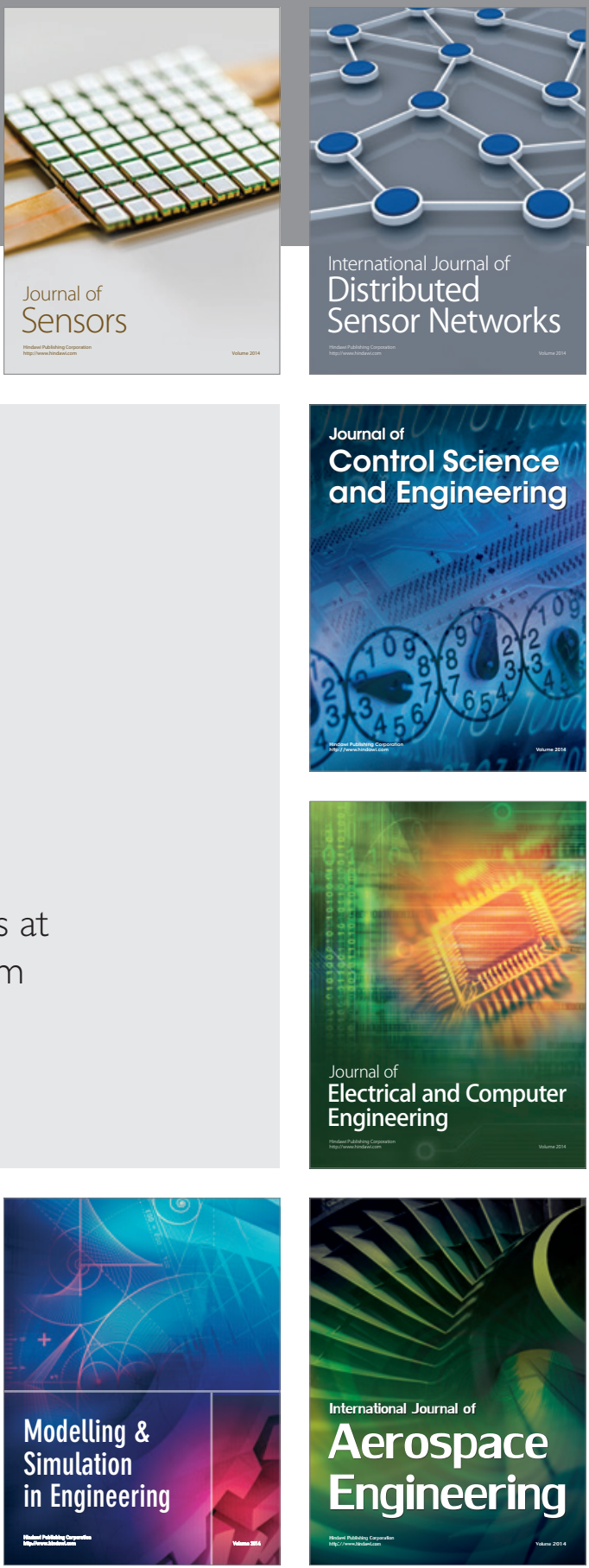

Journal of

Control Science

and Engineering
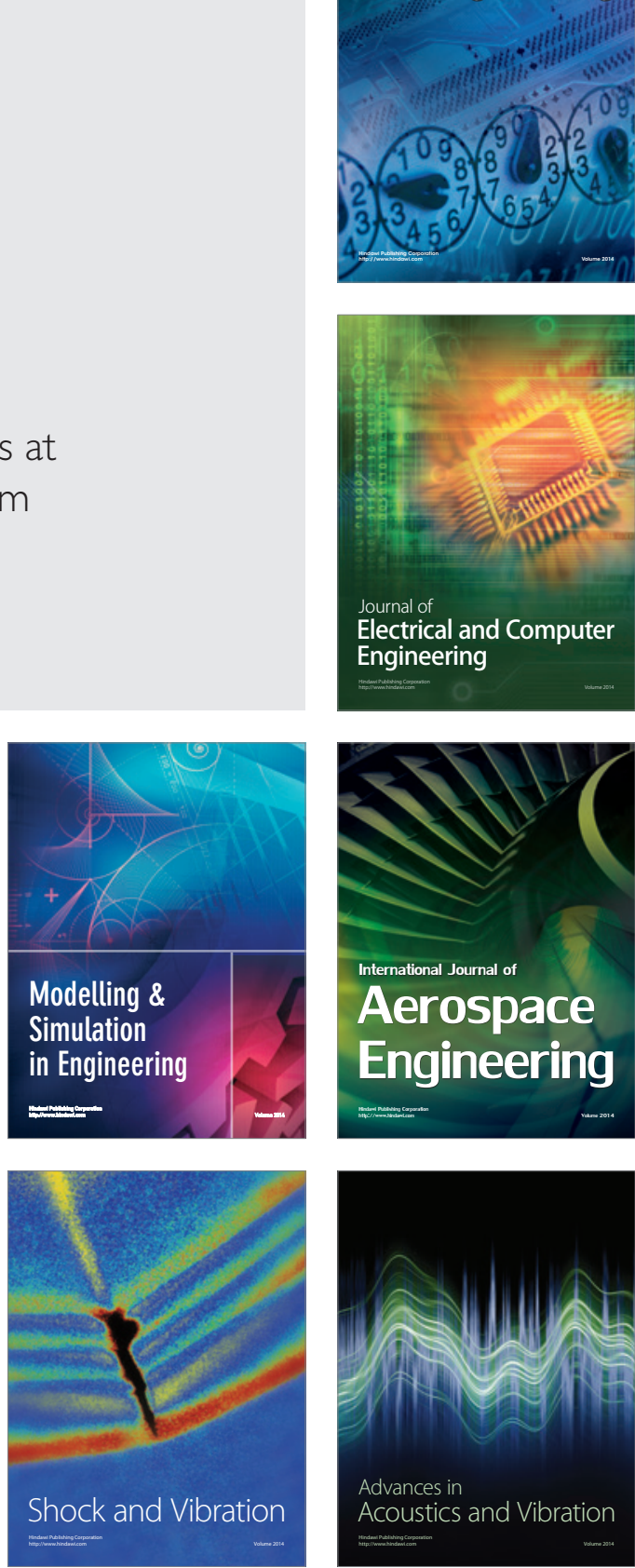